\title{
INTERSPECIFIC HYBRID PRODUCTIVITY AND ITS COMPONENTS
}

\section{Butenko Evhenia ${ }^{1}$ Klochkov Danylo ${ }^{2}$}

\section{DOI: https://doi.org/10.30525/978-9934-571-89-3_94}

Brother-sister crossing narrows down the genetic basis of starting breeding material, cultivars and, vice versa, its increase with the involvement of conspecific cultivars in breeding practice enables not only to introgress genes unavailable in cultivars, but also to have a positive impact on the productivity of potato offspring.

The nature of the inheritance of quantitative potato characters, which include productivity, can be explained by superdominance. The maximum hybridous vigour by character takes place when all four alleles in burdock are different. This state of alleles is called heteroallelism or tetraallelism. The hybridous vigour in potato is mainly based on the non-additive interaction of genes, which is manifested through the internal locus (superdominance) and interlocus (epistasis) interaction of genes and alleles. The experimental confirmation of the above is found in the works of many scientists [1, p. 7-8].

Proceeding from the fact that most varieties of the early twentieth century came from a small number of initial forms, that is, were close in genetic terms, it is needless to expect the manifestation of hybridous vigour from their breeding use. The use of interspecific hybridization is driving in this respect. Therefore, the involvement of cultivars in breeding practice makes it possible to obtain heterotic progeny in terms of productivity. The above mentioned has found numerous confirmation regarding the species of $\mathrm{S}$. andigenum.

The effect of heterosis also occurs when crossing two wild species. In the five combinations with the participation of the parent form of samples of S. stoloniferum species and pollinators of S. chacoense (three populations), and S.simplicifolium and S.gourlayi species, the four ones are characterized by significant heterosis by productivity, and, for example, in the combination of S. stoloniferum (UK 82-34) $x$ S. chacoense (UK 21-8) with the maximum productivity of the best of parents (pollinator) of $25.0 \mathrm{~g} / \mathrm{plant}$, the average value of indicators among potato offspring is $69.8 \mathrm{~g} /$ plant [2, p. 25-28].

The phylogenetic remoteness of wild potato species from cultivated ones, as well as the natural evolution of the former, in contrast to the selection of the best forms among the latter by autochthons, makes it impossible to obtain high-yielding forms only in the case of using wild species in crossing. And, even when obtaining interspecies hybrids involving varieties and wild species, it is impossible to obtain offspring with a higher manifestation of yield than in standard varieties. To improve the manifestation of agronomic characters among progeny from interspecific crosses it is proposed to use backcrossing, discontinuous backcrossing, or self-pollination [3, p. 188].

\footnotetext{
${ }^{1}$ Sumy National Agrarian University, Ukraine

${ }^{2}$ Sumy National Agrarian University, Ukraine
} 
An important role in the manifestation of agronomic characters among potato offspring from interspecific crossing, including productivity, is played by the selection of varieties - a component of hybridization. In the process of backcrossing it is recommended that not only one, but different varieties should be involved in hybridization. When selecting the components of crossing, it is essential to pay attention to their photoperiodism, which determines the productivity of plants. Selecting varieties for breeding, one should give consideration to the fact that the genes of control over negative features can be available in their genotype [4, p. 3-5].

It has been found that for backcrosses of complex interspecific hybrids involving phylogenetically distant species, the dominant component of productivity is the plurality of potato tubers. It has referred both to the secondary interspecific hybrids and backcrossed material. The capability of producing large tubers is manifested to a lesser extent in such material [3, p. 190]. At the same time, among the significant part of the studied forms we have managed to combine the two components of productivity and to distinguish the selection valuable forms.

The use of promising backcrosses of interspecific hybrids in the creation of varieties has resulted in obtaining hybrids that have successfully passed the competitive-environmental (the varieties of Basis, Shchedryk) and state (Dneprianka, Podolianka, Zaviia) variety testing.

According to many researchers, the success in the creation of potato varieties is largely determined by the effective and proper selection of parental forms. This is especially true for the use of interspecific hybrids by crossing components, since not only positive, but also negative characters can be inherited with their participation in terms of practical application. It is offered to select parental couples by the ecological and geographical principle. The above mentioned is also the basis for obtaining heterotic forms according to certain characters [5, p. 12-14].

It is believed that parent forms may be selected based on the results of the evaluation of potato offspring from self-pollination. Extending this area of research, it is proposed to create self-pollinated lines of potato (inbreeding line) and then use them in heterosis breeding. At the same time, it should be noted that the application of this approach is limited to inbreeding depression, which accompanies the formation of potato offspring from self-pollination. For example, it is found that the average yield of hybrids is $8.5 \%$ higher than the original forms and $35.8 \%$ lower than that of potato offspring from self-pollination.

Another method of selecting parental forms is the use of test crossing. However, the conduct of such crossings does not provide for consistency in the work that significantly complicates the determination of potential capabilities of the crossing components. At the same time, we believe that the experience of breeders is largely formed on the basis of the use of test crossing.

According to the data of individual researchers, the genetic potential of parental forms, the interaction of hereditary factors in the formation of the zygote as a result of determining the combining ability of crossing components can be characterized to the fullest extent. 
In practice, this is done using the following approaches: diallel crossing, top cross or poly cross and free and uncontrolled self-pollination. It is believed that more complete information on the inheritance of characters of crossing components can be obtained by using diallel crossing.

The foregoing shows that it is too difficult to obtain potato offspring under complete diallel scheme. In this regard, top crosses are widely used to determine the genetic potential of parental forms. Their simplest form is a single test top-cross, when a female parent is pollinated by one highly fertile pollinator. In addition to the ability to set fruit effectively, the requirements for such tester include its broad genetic basis and high adaptability to growing conditions. Due to the minimum number of combinations determined by the number of maternal forms, this method of estimating heredity is the least expensive. At the same time, its information content is minimal. When using it, it is impossible to isolate the effects of general combining ability (GCA) and specific combining ability (SCA). The disadvantage of a single test top-cross is the influence of the specific interaction between hereditary factors of the pollinator and various parent forms on the manifestation of characters.

Based on the above, the two-, three-test schemes are more frequently used. This eliminates the disadvantage of diallel crossing, that is, the inability to obtain offspring under the complete scheme and, at the same time, enables to determine GCA and SCA. The relatively lower costs of conducting research, obtaining adequate information have resulted in the widespread usage of two-, three-test top-crosses.

Multi-test top-cross has much more opportunities. Its essence is in the use of two sets: the samples in one set are used as maternal forms, and in the other - as pollinators. An additional advantage of multi-test top-cross is the possibility of determining the coefficient of inheritance.

The program providing for selection of the best maternal forms and pollinators according to the general combining ability has been implemented to determine the combining ability of parental forms. Its essence is as follows: on the first stage maternal forms are pollinated with a pollen mixture. After evaluating the populations the best samples by GCA are selected, and on the second stage they are used as testers in case of multi-test top-cross.

Thus, the difficulty in involving interspecific hybrids, their backcrosses in the breeding practice is based on the significant difference between them, depending on the schemes of their obtaining, the number of species involved in crossing, backcrossing scale, effective control over agronomic characters, the optimal selection of varieties of parent components, etc. The study of these issues will enable to significantly improve the efficiency of the use of interspecific hybrids in the breeding practice and obtain new varieties with the high manifestation of characters, which are non-typical for S.tuberosum or have little expression in cultivated varieties.

Selecting the best forms based on the analysis of their origin, in order to obtain data more accurate than on the determination of the phenotypic control of characters, it is essential to determine the combining ability of hybrids by assessing the offspring from top-crosses. 


\section{References:}

1. Bondarchuk A.A. (2008). Status and priority directions of development of potato industry in Ukraine [Stan ta priorytetni napryamy rozvytku haluzi kartoplyarstva v Ukrayini]. Agrarian Science. Issue. 37. P. 7-13.

2. Osypchuk A.A. (2009). Potato breeding in Ukraine taking into account growing zones [Celektsiya kartopli v Ukrayini z urakhuvannyam zon vyroshchuvannya]. Agrarian Science. Issue 37. P. 25-31.

3. Simakov E.A. (2007). Methodological aspects of introgressive potato breeding for disease resistance [Metodologicheskiye aspekty introgressivnoy selektsii kartofelya na ustoychivost' $\mathrm{k}$ boleznyam]. Potato Farming. Minsk. Vol. 12. P. 188-197.

4. Nazar S.H. (2010). Results of potato breeding using the complex interspecific hybrid 77.583/16 and simple intercultivar hybrid 79.544/61 [Rezul'taty selektsiyi kartopli pry vykorystanni skladnoho mizhvydovoho hibryda $77.583 / 16$ ta prostoho mizhsortovoho hibryda $79.544 / 61]$. Potato Farming. Agrarian Science. Issue 39. P. 3-12.

5. Podhaetskyi A.A. (2006). Genetic resources of potatoes in Ukraine [Henetychni resursy kartopli Ukrayiny]. Potato Farming. K.: Agrarian Science. Issue 34-35. P. 12-22. 